\title{
Interest group influence and interinstitutional power allocation in early second-reading agreements: a re-examination of aviation emissions trading
}

\author{
Maja Andlovic, Wilhelm Lehmann \\ European Parliament
}

\begin{abstract}
With the extension of codecision the European Parliament and the Council have pushed for a more rapid adoption of legislative acts. However, this increase in efficiency comes at a political price. It reduces opportunities for the Parliament to be perceived as an arena for political arbitrage. It may also change the playing field for different categories of stakeholders in normatively undesirable ways. This article addresses two widespread claims: business interests may be better equipped to influence the outcome of early adoptions than other groups and the European Parliament's policy making powers may not profit from early adoptions despite presumed gains in efficiency. The results of our case study provide some support for both: business stakeholders seem to adapt better to the more secluded setting and the European Parliament is not achieving its initial goals in this early second-reading adoption.
\end{abstract}

KEY WORDS co-decision; Council; early second reading agreements; European Parliament; lobbying 


\section{INTRODUCTION}

Early agreements and informal interinstitutional negotiations have become the subject of intensive research and theorizing. A recent special issue of the Journal of European Public Policy collected several important contributions to this debate, ranging from intra-institutional power distribution to normative analyses of democratic legitimacy (see Héritier 2013 for an overview). Some work has also focused on the conditions under which key actors prefer to "go informal" (Reh et al. 2012). In this paper we intend to make an exploratory contribution to this debate, based on insiders' views in an early second-reading agreement dossier. More precisely, we aim to shed some light on two politically salient issues, the influence of different types of stakeholders and the weight of the European Parliament (EP) as co-legislator. We chose the inclusion of aviation emissions in the EU's Emission Trading System (ETS) as our empirical case.

The EP has long encouraged greater interest group participation, since their involvement was seen to increase the potential for more transparency and democratic legitimacy. There are now over 4,500 lobbyists holding access badges for the European Parliament, the equivalent of six lobbyists for each MEP (Burley et al, 2010: 27). In order to adapt to the institutional demands brought on by co-decision, such as increased workload and the prolongation of legislative procedures, the EP and the Council have developed new procedures, such as trialogues. We aim to clarify whether increased use of trialogues reduces the ability of some interest groups to impact policy making in the EP and the Council.

With codecision the EP has evolved to become a full co-legislator across a wide range of policy areas (Lehmann 2009, Marshall 2010). A greater workload and stronger demand for expertise and technical information represents a new entry point for interest groups able to provide quality input. In the full co-decision procedure a proposal may go through up to three readings, depending on the parties' willingness to negotiate and agree. As a result, there is a risk of long legislative procedures (Häge and Kaeding 2007: 342). Trialogues were introduced with the aim to facilitate negotiations between the EP, the Council and the Commission prior to formal voting. They provide a setting which enables informal legislative negotiation in order to avoid a gridlock. Already in 2006, more than $94 \%$ of the Commission's proposals were negotiated through informal contacts (Kardasheva 2009: 25, 78).

Another important innovation is the fast-track legislation introduced by the Amsterdam Treaty in 1999. First reading deals have surged from $17 \%$ in $1999 / 2000$ to $80 \%$ in $2008 / 2009$ (European Parliament 2009). According to the latest EP Activity Report the trend of more agreements at an early stage continues in the first half of the $7^{\text {th }}$ legislative term: $78 \%$ of legislative dossiers were concluded at the first reading, $18 \%$ at the second and only $4 \%$ in conciliation. In addition, the conclusion of early second reading agreements has emerged: the EP gives assurance to the Council that, if it adopts the agreement unchanged in its common position, Parliament's position is to be adopted without amendments at second reading. The following case study is an example of this type of procedure. Overall, the Council's position at first reading was approved without amendments ("early second reading" agreement) in $7 \%$ of all cases, while $11 \%$ were classical second reading agreements (European Parliament 2012). ${ }^{1}$ Already during the $6^{\text {th }}$ term of the EP (2004-2009) there was a shift from first reading agreements to early second reading agreements. Sometimes these deals are also referred to as quasi-first reading agreements. During the 6th term $10.8 \%$ of all second reading dossiers were early agreements (Neuhold and Ruiter 2010: 4, 6, 21). 
The participation of interest groups can be seen as a complementary mechanism of democratic input (Greenwood, 2007: 333) because they enable the EP to have a closer link with EU citizens, providing it with important information about their preferences (Saurugger 2008). Increasingly, intra-institutional factors are taken into account since they influence preference aggregation within the institutions and determine lobbying strategies from the outside (Coen and Katsaitis 2013; Judge and Earnshaw 2011). For instance, the EP has become a prime target for various interest groups because it represents an attractive avenue for those unsuccessful to achieve their objectives domestically (Warntjen and Wonka 2004). If MEPs or party groups share similar policy preferences stakeholders may achieve their goals by lobbying the EP (Cirone 2011: 5). On the other hand, trialogues could make it easier for the Council to influence the rapporteur, in particular when Member States (MS) in the Council are under pressure from powerful industry groups. This raises the empirical question how recent procedural changes modify the influence of different interest groups and whether they make it easier or more difficult for the Parliament to achieve its preferred outcomes.

\section{THE EFFECTS OF EARLY AGREEMENTS: THEORY AND HYPOTHESES}

\section{Impact on different interest groups}

Actors such as environmental NGOs, think tanks, consultancies, economic pressure groups seeking to influence policymaking can be divided into two main types: (1) Private economic interest groups/for-profit actors (a coalition of private business and economic interests represented in Brussels) and (2) public or societal interest groups/not-for-profit actors (organisations representing public interests such as the environment, human rights or animal welfare). We follow Beyers' definition of public interests as common good-oriented interests which can be "linked to broad and general segments of society" while business interests are focused on specific economic, professional or social aims within a general objective of improving regulations for their own benefit and are usually defended by "well- circumscribed and concentrated constituencies" (2004: 218). There are differences between these categories, notably their access to key players and their ability to adapt to new institutional settings. In addition, business pressure groups outnumber public interest groups by approximately four to one (Civitas 2011).

Extensive use of trialogues and early agreements has important consequences for different interest groups. For instance, the EP's involvement in informal bargaining reduces its openness to outside interests because access to trialogues is limited to a restricted set of actors (the Coreper Presidency, the Chair of the responsible EP committee, Parliament's rapporteur and shadow rapporteurs and the responsible Commissioner; officials and desk officers from each institution follow the negotiations). There are no attendance records, thus participants can only be known indirectly. Outside actors rarely know which issues are on the negotiating table (Stie 2010: 198). Also, trialogues have reduced the time frame of many legislative procedures (Kardasheva 2009: 24). Hence, interest groups have less time to influence the debate albeit the drafting of amendments for EP committees represents one of the most important access points for them. Interest groups are responsible for 75 to 80 percent of the initial drafting of amendments in most active legislative committees (Earnshaw and Judge 2002: 64). 
Informal negotiations have also affected the EP's internal structures and processes, strengthening some actors and weakening others. In a full conciliation procedure Parliament's delegation has absolute priority for obtaining technical resources such as meeting rooms or translation of interim documents (Huber and Shackleton 2013). Committee rapporteurs and shadow rapporteurs seem to have won more control over the legislative process than committees as a whole (Farrell and Héritier 2004: 1200; Judge and Earnshaw 2011). Since contact to decision-makers is largely restricted to insiders (Derschewsky 2008: 31; Gullberg 2011: 471), many interest groups might have difficulties to gain such access.

However, the ability to establish effective contacts with EU institutions is an important factor for wielding influence. Stakeholders enjoying continuous contacts with EU officials are better informed and thus better able to voice their concerns and proposals (Bouwen 2002: 17, Eising 2007: 332). In order to establish links with relevant policy actors, groups have to be able to afford good presence in Brussels. Consequently, stakeholders with limited resources or personnel are at a disadvantage (Hallstrom 2004: 178). While a resource-rich association has a $99 \%$ probability of having two or more contacts with ministers or their equivalent on EU legislation over a two-year period, a resource-poor association has only a $28 \%$ probability (Dür and Mateo 2012: 18).

The capacity to provide relevant policy information is a second factor influencing the standing of interest groups because of the interdependence between interest groups and institutions: in exchange for access and information the EU institutions demand technical expertise and information, citizen support and economic power (Klüver 2013). In areas such as market integration and regulation, standard-setting and external commercial policy, business interests are able to provide the EP with specific and confidential information about likely economic and technical effects of EU policies, their repercussions on domestic law and the political responses of their member organisations (Eising 2007: 336).

As a general approach, the EU institutions aim to strengthen civil society participation. While some time ago MEPs rated public interest representatives higher in their capacity to exert effective lobbying influence (Greenwood 2007) there also seems to exist a clear bias in favour of resourceful actors (Eising 2007: 357). For example, MEP Jens Holm commented on the relatively weak position of the European Consumers' lobby BEUC: "[One person working on cosmetics] is certainly capable, but against 20 fulltime lobbyists and contracted consultants the playing field is obviously unequal" (quoted in Burley et al. 2010: 28). It appears likely that private interest groups adapt more easily to the increased use of informal trialogues. They invest a greater amount of resources in monitoring processes and the extension of networks in order to derive relevant information about parliamentary power structures and shifts at early stages.

Some of the above arguments may theoretically apply to competent public interest groups as well but their limited capacities to monitor and persuade make it less probable that they take advantage of restricted access situations. Trialogues characterised by a limited number of participants may even be detrimental for them since negotiations taking place behind closed doors offer fewer opportunities for public campaigning, organising petitions and gathering support among citizens in the MS. Yet the ability to mobilise public support is one of the main advantages of public interest groups. To summarise, public interest groups are on average less able to invest resources into monitoring and building networks and have more difficulties in gaining access to relevant actors.

Following from this, our first hypothesis is: 


\section{H1: Increased use of informal trialogues makes it more difficult for public interest groups to influence policy outcomes. Elite (notably business) interest groups are less affected.}

\section{The influence of the European Parliament versus the Council}

Informal arrangements and their impact on the inter-institutional balance have attracted considerable scholarly attention (Farell and Héritier 2003, Häge and Kaeding 2007, Häge and Naurin 2013, Reh et al. 2012). A priori, the EP and the Council are equal partners in trialogue negotiations but informal practices may significantly affect the power of the EP to obtain its desired political outcome (Costello and Thomson 2013). For the moment, research shows significant variation with respect to the consequences of the codecision procedure on the balance of power between the EP and the Council (Héritier 2013, Ripoll 2013).

We first consider three arguments that have been advanced in favour of the Parliament. First, under certain conditions first reading agreements seem to show an increasing willingness of the Council to take on Parliament's amendments and, as a result, the EP may be considered to have a stronger impact during trialogues (De Clerck-Sachsse and Kaczyński 2009: 12). The Council is represented in trialogues by the deputy ambassadors of the Coreper, who are responsible for overseeing and coordinating the work of dozens of working groups, and (sometimes inexperienced) national officials from the MS holding the Presidency. Thus the Council may not afford to scrutinise all files through the whole procedure but restrict its attention to issues that it considers most important. As a result, it could be easier to extract concessions from the Council (Häge and Kaeding, 2007: 354).

Second, the Council Presidency may be under pressure to accelerate the legislative process in order to obtain an early agreement because it has only six months to realise its objectives. Unless the salience of an issue for the Council outweighs its anticipated costs of engaging in conciliation, it should agree to participate in informal trialogues and make policy concessions to avoid conciliation. The Parliament would thus have a bargaining advantage in trialogues (Häge and Kaeding 2007: 342, 357).

Finally, the EP's bargaining position during trialogues may be better due to greater insensitivity to failure. This might make it more willing to bring down or block legislation (Farrell and Héritier 2003: 594). The Council is supposed to have a greater incentive to pass legislation in order to avoid blame at the domestic level. In case of failure individual Members of the European Parliament may be less likely to be blamed than MS governments (Farrell and Héritier, 2005: 282).

However, recent scholarship has argued that trialogues do not necessarily imply that the European Parliament will succeed in striking a successful legislative deal (Ripoll 2013). While not specifically focusing on the impact of informal trialogues, Costello and Thomson measured bargaining success in terms of the relative distance of the EP and Council from the policy outcome and concluded that the Council is considerably more powerful than the EP under codecision, despite the formal parity between the institutions. They also observed that Council has a bargaining advantage when it is closer to the status quo, which is often the case because of Council's 'conservatism' (Costello and Thomson 2013: 1037). It has also been suggested that it is necessary to examine the relationship between the nature of the policy area and the cost of new legislation (Kardasheva 2009: 237, 277). The EP's influence would depend on the 
distribution, level and proportionality of costs and benefits imposed by its amendments (Burns 2005: 490, 497; Burns et al. 2013).

During their five year mandate negotiating MEPs are able to acquire more experience in trialogues than Council Presidencies. On the other hand, the Presidency is assisted by Coreper and the Council Secretariat, which have both the necessary level of negotiation experience and a detailed knowledge of MEP's negotiation techniques. Costello and Thomson point out that the Council can easily obtain information on whether the EP is internally divided because committee meetings and votes are public (2013: 1037). The Council may use these internal divisions to play EP actors off against each other, thus undermining a coherent negotiation strategy. Furthermore, the Council can maintain its influence by using its relatively clear mandates and by presenting a unified front during negotiations because its representatives do usually not disclose the positions of individual MS (Costa, DeHousse and Trakalova 2011: 27). Strong expertise from MS at the disposal of Coreper also plays an important role in enabling the Council to enter the trialogue negotiations well prepared and with a clear general approach. In addition, there is a clear advantage in the amount of time the Council has to prepare for trialogues as they are usually able to start while the EP is still deliberating on which members and committees will work on the proposal (House of Lords 2009). EP rapporteurs are uncertain about the prospects of their proposals because trialogues take place before the dossier has been put to the plenary (cf. Yordanova 2011: 612). The rapporteur's experience, negotiating skills, interest and level of involvement with the file cannot fully compensate for this structural weakness. Although the Parliament has made great efforts to increase the availability of expert knowledge for rapporteurs, there is still an imbalance in favour of the Council (Costa, DeHousse and Trakalova 2011: 28, 29).

In conclusion, the smaller number of participants involved in in camera negotiations may make it easier for the Council to influence the rapporteur, in particular when MS in the Council are under pressure from powerful industry groups, and enable the Council to achieve its preferred outcomes, at the expense of the EP. Our second hypothesis is therefore:

\section{H2: The small number of key actors and negotiators increases the Council's options to determine the final policy outcome.}

\section{CASE STUDY: THE INCLUSION OF AVIATION IN THE EU'S EMISSION TRADING SYSTEM}

\section{Short history of the procedure}

In 2006 the Commission transmitted its legislative proposal to amend Directive 2003/87/EC as to include $\mathrm{CO}_{2}$ emissions from aviation into the ETS. The proposal was part of an effort to tackle aviation's small but fast-growing contribution to climate change. The Commission proposal imposed a cap on $\mathrm{CO}_{2}$ emissions for all airplanes arriving or departing from EU airports, while allowing airlines to buy and sell pollution credits on the EU carbon market. It aimed to include flights between EU airports from 2011 and flights departing from and arriving in the EU from 2012. In December 2007 the Environment Council agreed on a common position on the Commission proposal. However, the EP deemed the Commission's proposal too weak and proposed a series of amendments in order to introduce stricter measures and thus strengthen the Commission's proposal, with potentially costly consequences for the airline 
industry. MEPs insisted, for instance, on full auctioning of allowances, a multiplier requirement and earmarking of revenues generated from the auctioning of emission permits. According to the airline industry, full auctioning combined with a multiplier requirement would result in $€ 15$ billion extra costs per year (EurActiv, 7 June 2007).

Since EP and Council failed to agree on these and a number of other issues, several trialogue meetings took place in June 2008, towards the end of the Slovenian Presidency. At their conclusion, the EP voted on 8 July 2008 in favour of including aviation emissions in the ETS as of 2012. ${ }^{2}$ Despite the EP's strong support for stricter measures throughout a three-year period, the final outcome was a relatively weak directive. According to several observers it will not make a real difference in tackling climate change. For example, the European Federation for Transport and Environment (T\&E) considered the proposal "too weak" because it would only lead to emission reductions of 3\% (EurActiv, 11 October, 2007). Another NGO described the inclusion of the sector in the EU-ETS as "no more than a minor first step" (EurActiv, 08 March 2011). Such views were confirmed by the Commission's impact assessment carried out in 2006: instead of aviation emissions growing by $83 \%$ between 2005 and 2020 under a 'business as usual' scenario, they would grow by $78 \%$ under a scenario matching the terms of the new directive (Corporate Europe Observatory (CEO), 2008: 8).

\section{Method}

We chose this "early second-reading" agreement because the private interest groups involved had the required conditions to access EU institutions effectively (financial resources, ability to provide relevant information, economic clout). The Council was able to formulate a cohesive opinion and to speak with one voice. Furthermore, powerful MS in the Council supported the preferences of industry groups. Hence, this scenario united several key factors discussed in the previous section.

Our evidence originates from 11 semi-structured expert interviews conducted with negotiators, both inside and outside the institutions, over a period of three months (see annex 1). We focused on key actors involved in the negotiations of the directive and identified officials responsible for the policy areas linked to our case study, i.e. environment, transport, and industry. In addition, interviews were conducted with officials working for Committee of Civil Liberties (LIBE) to obtain a complementary perspective on the impact of early adoptions in other policy areas. Policy officers working for environmental NGOs and public affairs consultancies were included to provide views from stakeholders.

The period during which we conducted the interviews (summer 2012) allowed for some distance and reflection on the interlocutors' experiences. Some interviewees answered questions in writing. The information derived from these expert interviews was combined with text analysis of press and stakeholder documents, using the methodology of a qualitative analytical narrative (cf. Héritier and Karagiannis 2011).

\section{The influence of different stakeholders}

Under the final agreement, all flights taking off and/or landing in the EU will be included in the ETS from 2012. Airlines will have to meet emission caps (97\% of 2004-2006 average emissions in 2012, then $95 \%$ from 2013) or buy extra carbon credits in the "open market", e.g. from other sectors. Eighty-five per cent of the emission permits required by airlines will be free and the remaining $15 \%$ will be auctioned (CEO 2008: 3 ). 


\section{[Table about here]}

The above table summarizes the EP's principal amendments: earlier start date (the EP voted to include all flights from 2011), stricter cap (90\% of 2004-2006 average emissions), a separate, closed ETS for aviation (in order to prevent airlines buying allowances from other industrial sectors) and full auctioning of allowances (100\%). However, the final agreement did not reflect these amendments.

Environmental interest groups welcomed the EP's efforts to strengthen the Commission's proposal and proposed the following improvements: to set a cap which does not exceed $50 \%$ of the average level of emissions in 2004/2006 for the phase ending in 2012; to allocate $100 \%$ of the allowances by auction; and to include all flights departing from and arriving in the EU in the scheme from 2010. The aviation industry, represented by the International Air Transport Association (IATA) and the Association of European Airlines (AEA), lobbied against the inclusion of aviation in ETS. An industry-sponsored study claimed that the Commission's proposal would slash airlines' profits by more than $€ 40$ billion from 2011 to 2022 and in doing so 'jeopardise the long-term viability of the European aviation industry' (EurActiv 2007). The AEA's spokeswoman expressed the aviation industry's position: 'It will be a burden and it might be a heavy burden. We operate in a very competitive sector, and we cannot afford to offload the costs on passengers' (EurActiv 2007). The chief executive of Ryanair stated: 'These clowns in the European Parliament seem determined to destroy the European airline industry with these discriminatory taxation penalties' (CEO 2008: 3).

Several important factors contributed to the EP's vote in favour of an agreement largely reflecting the Council's preferences: the aviation industry, well endowed with financial resources, led an aggressive campaign, based on media advertisements, lobbying through various consultancy firms in Brussels, and direct targeting of MEPs. E.g., IATA spent considerable resources on a so-called green-washing campaign, aiming to promote a public image of aviation as a green industry, claiming for example that the aviation industry invested in innovations to improve fuel efficiency and supported research into solar power (GreenAir 2008). During one of our interviews with an environmental interest group, the representative stated that such organisations are "simply outnumbered". Furthermore, lack of resources prevents them from being able to campaign on all issues with the same efficiency as private interest groups. Due to the complexity of the whole climate and energy policy package, the environmental NGOs were not able to put in the same amount of effort to counter the aviation industry (Desk Officer, Greenpeace, 13 July 2012).

The aviation industry used its economic clout to put pressure on certain MS, in particular Germany. As mentioned, business groups may use member firms' threats to relocate investment and employment across borders to gain influence (Dür, De Bièvre 2007: 22). Indeed, Lufthansa's chief executive stated: 'Should the European Union go ahead with its plan we would have to think about relocating.' He hinted at the possibility to move hub operations from Germany to Switzerland (CEO 2008: 9). A green NGO representative mentioned that industry interest groups were effective in lobbying the Member States while green NGOs were not successful in doing this. This could be attributed to difficulties that Green NGOs have in coordinating their Brussels lobbying activities with the national level due to lack of resources and staff. It is interesting to note that green NGOs were able to contact the rapporteur but that this was not sufficient to make an impact. According to the NGO member the industry groups were able to lobby both MS as well as individual MEPs from certain MS, supposedly most 
affected by the implementation of the directive. These MEPs, having detailed knowledge of the directive, were instrumental in the last stages of the trialogues. The final outcome was a result of the combined efforts of MS and aviation industry (Desk Officer, Greenpeace, 13 July 2012). The aviation industry also challenged the Commission's impact assessment, which estimated the overall effect of the directive as very small in terms of overall GDP growth and employment (European Commission 2006). An industry-sponsored impact assessment presented dramatically different findings: the inclusion of aviation in the ETS would mean between 8,000 and 42,000 fewer direct jobs by 2022 (CEO 2008: 8).

It has been claimed that stakeholders have a higher chance of success if their threats are perceived by the public as relevant, severe and credible (Skodvin et al. 2010: 869). In our interviews Coreper officials suggested that the EP stands a better chance of extracting concessions from the Council later in the co-decision process, after the first reading, because the EP has stronger ties with the media. They held that the EP is more apt than the Council in using its ties with the media as a tool of political pressure, portraying itself as a champion of citizens' rights. This tactic is particularly effective during plenary sessions likely to attract media attention and popular support. Since a large number of its debates are closed to the public the Council has less interest in receiving press coverage (Coreper official working party Aviation, 24.7.2012, and Coreper official working group Environment, 24.7.2012).

Similarly, interviews with officials from the EP Industry and the Environment committee suggested that trialogues are not an obstacle for well-organised interest groups. The latter were usually able to establish contacts with the EP's rapporteur during the drafting stage. At the same time, trialogues might prevent some groups from knowing exactly how the negotiations evolve, unless they have a very reliable contact. Insufficiently organised interest groups may have problems to deal with confidential trialogues (Administrator European Parliament, ITRE committee, 6.7.2012, and Administrator, ENVI committee, 13.7. 2012).

An interview with a Brussels European public affairs consultancy showed that private interest groups are familiar with the legislative procedure and have adapted well to this new setting. Our research conducted with officials from the three political institutions suggests that during trialogues private interest groups are well informed on the content and outcomes of negotiations within a matter of hours. Immediately after trialogue meetings responsible officials receive briefings prepared by private interest groups with suggestions, amendments and recommendations for future negotiations (three Coreper officials: working party Aviation, working group Environment and working group Transport, 24.7.2012). In contrast, public interest groups are in a disadvantaged position due to greater difficulties in gaining access and to a reduced time frame. As an early agreement dramatically reduces the time for lobbying activities they tend to focus their efforts on the debates preceding the trialogue and even to lobby the EP before the Commission has transmitted its proposal. Industry lobbyists focus more on the rapporteur, hence trialogues do not change their ability to access relevant policy makers (Official EPACA, 8 August 2012).

\section{The impact of the early agreement on the European Parliament}

Turning to our second hypothesis we start from the observation that the Commission, the Council and the EP (including its German Conservative rapporteur) were in principle keen to reach an agreement. Slovenia, holding the Council's Presidency, intended to reach an agreement since its successor France signalled that it did not want to deal with this issue. One of the interviewees from Coreper noted: 'the time pressure takes its toll and sometimes we might 
agree on issues, that we would not agree on if we had more time' (Coreper official, working group Transport, 24 July 2012). On the other hand, in a dossier of great political importance the Presidency has a strong motivation to adopt legislation and puts considerable pressure on the other institutions. Several interviewees observed that the Council Presidency often exerts high pressure on the EP during negotiations, especially if the rapporteur comes from the Member State (MS) holding the Presidency (Desk officer, EU Commission, DG Climate, 17.7.2012, three officials, EP LIBE committee, 5.7.2012 and 6.7.2012).

In our case the Presidency presented the rapporteur with a 'take it or leave it' proposition, not willing to back down even if this would entail conciliation. A Coreper representative expressed surprise that the EP's rapporteur had decided to accept the compromise largely reflecting Council's preferences during the final trialogue, notably in view of the fact that he had included all amendments from the first reading in his draft recommendation for second reading (Official, Coreper working party Aviation, 24 July 2012). According to several interviewees, the Council considerably benefited from strong expertise at its disposal. MEPs' objectives were frequently qualified by concerned stakeholders as being of a political nature and impractical for financial or administrative reasons. Coreper interviewees held that the EP sometimes fails to express its position clearly during the first stages of trialogues. In their view, the complexity of inter-party compromise makes the formulation of a strong, unified position very time-consuming.

At the international level, the Commission's proposal received a negative response from the US, which threatened the EU with legal action in the WTO if it went ahead with its plans to include foreign airlines in the ETS (CEO 2008: 13). Companies' internationalization and economic weight increase their veto powers because producers operating in international markets can more credibly threaten to shift investments than firms 'nested in domestic markets' (Eising 2007: 337). These concerns were mainly channelled through the MS representations (Official, Coreper working party Aviation, 24 July 2012).

The fact that air traffic was ultimately included in the ETS could be seen as a success for the European Parliament. However, a closer look at the directive reveals that the outcome will not significantly affect the aviation industry. This is clearly stated in the Commission's own impact assessment and explains the environmental interest groups' disappointment. For instance, Friends of the Earth claimed that the final compromise was so weak that "it will have little impact on the rocketing growth in carbon dioxide pollution from flying" (Euractiv 2007). According to a report drawn up by a group of academics funded by the US Federal Aviation Administration the aviation industry could even hope for a $€ 2$ billion windfall profit from the ETS. The aviation spokesman for the European environmental pressure group Transport and Environment said that airlines '[would probably cover] their real costs by passing them on to passengers with minimal impact on their businesses' (EurActiv 2012).

Overall, our evidence provides some support for the claim that trialogues do not systematically increase the EP's influence. Rather, the policy outcome depends on factors such as the saliency of a proposal, the policy area and the precise nature of the package deals made to reach a compromise. As the EP's amendments potentially led to considerable costs for the air industry and could furthermore have resulted in negative economic consequences in many MS, particularly Germany, it could not include its initial amendments in the final directive. The aviation industry was able to obtain a policy outcome closer to its preferences than to those of the EP or the environmental pressure groups.

Under certain conditions, trialogues may indeed negatively affect the EP's legislative influence because the Council enters trialogue negotiations well prepared, with a clear position, and relies 
on experts from MS and other expertise. The in camera setting of trialogues enables the Presidency to exert considerable pressure on the EP's rapporteur. Additional pressure from the Commission on Parliament's rapporteur may further enhance the Council's chances of success (Desk officer, EU Commission, DG CLIM, 17 July 2012).

\section{CONCLUSION}

The current situation of the regulation of aviation emissions provides a further indication of the power of aviation companies: facing continuing foreign and industry pressure, the EU Commission announced in November 2012 its intention to 'Stop the Clock' (to suspend for one year the extra-territorial elements of the ETS). In April 2013, the EU decided to temporarily adjourn enforcement of the ETS requirements for flights operated in 2010, 2011, and 2012 from or to non-European countries, while continuing to apply the legislation to flights within and between countries in Europe. The main aim was to allow time for the International Civil Aviation Organization (ICAO) Assembly to reach a global agreement to tackle aviation emissions in autumn 2013 (European Commission 2013). More recently, on 16 October 2013, the European Commission submitted a proposal to amend the ETS to exclude emissions that occur outside EU airspace (Keating 2013).

As our conclusions are based on a small number of semi-structured interviews further evidence across policy domains, legislative dossiers and stakeholder categories is required to draw wider conclusions on a growing democratic deficit in European governance through informal decision-making. In this context, we would like to note that the claim that interest groups can help to augment legitimacy is contested (eg, Michalowitz 2004). Nonetheless, many practitioners and scholars argue that trialogues negatively affect democratic legitimation. The EP derives its legitimacy not only from the fact that citizens elect it directly but also from the openness of its proceedings. The secrecy of informal trialogues reduces this transparency. In particular, scrutiny of the legislative process by MEPs, national parliaments or the wider public becomes more difficult. Trialogues also reduce the ability of individual MEPs to participate fully in legislative bargaining (Kardasheva, 2012: 6). If most directives are adopted by a small group of MEPs and the Council Presidency during trialogues, the EP's and even the Council's role may be reduced to rubber stamping (Hix 2009: 2). This was recently underlined by an EP committee chair: 'We should make sure in future that we reach fewer first-reading agreements (....) if we adopt everything during the first reading Parliament will be depriving itself of its rights' (Groote, 2011). One preliminary reaction to this deficit of participation since the introduction of early conclusions was to broaden the attendance of trialogue meetings (Rasmussen and Reh 2013: 1019).

The EP Activity Report on the $6^{\text {th }}$ term (European Parliament 2009) points out that public and media are interested in political confrontation, in particular on highly salient issues. In the event of an agreement reached during trialogues there is no open debate or visible confrontation before the adoption of the final act. One policy advisor in the EP observed that if a decision is not reached at the first reading, the wider public gets an opportunity to protest and there is a stronger chance that the issue will become politicised and attract public attention. This was also reflected in President Schulz' acceptance speech: 'If our Parliament is to become more visible, if greater attention is to be paid to its views, a rethink of the issue of first-reading agreements is also essential' (17 January 2012). This paper has contributed some qualitative empirical indications that new approaches in legislative decision-making, such as early agreements, are an important variable to be taken into account in future research on codecision and the EU's 
legitimacy. Many of its implications for legislative decision-making on political versus technical and redistributive versus regulatory dossiers remain to be explored.

Biographical notes: Maja Andlovic is a former Robert-Schuman-Trainee of the European Parliament. Wilhelm Lehmann is Research Administrator at the European Parliament.

Address for correspondence: Wilhelm Lehmann, European Parliament, Rue Wiertz 60, B1047 Brussels, Belgium. Email: wilhelm.lehmann@ep.europa.eu

\section{ACKNOWLEDGEMENT}

The statements made in this paper are strictly personal and cannot be interpreted as representing an official position of the European Parliament. The authors would like to thank Alexander Katsaitis, Randall E. Newnham and Els Vandenbosch for their comments on an earlier draft. We are also grateful to three anonymous reviewers for their critical observations and very helpful suggestions.

\section{NOTES}

1 See annex 2 for statistics up to June 2013.

2 OJ L 8 of 13.01.2009, p. 3. Müller and Slominski (2013) provide a detailed account of the procedure. Further technical details may be found at http://www.europarl.europa.eu/oeil/popups/ficheprocedure.do?reference=2006/0304(COD)\&l= en\#finalAct

\section{REFERENCES}

Beyers, J. (2004) 'Voice and access. political practices of European interest associations', European Union Politics 5(2): 211-40.

Bouwen, P. (2002) 'Corporate Lobbying in the EU: the logic of access', Journal of European Public Policy 9(3): 365-90.

Burley H., Dinan, W., Haar, K., Hoedeman, O. and Wesselius, E. (2010) Bursting the Brussels bubble, Brussels: Alliance for Lobbying Transparency and Ethics Regulation in the EU (ALTER-EU).

Burns, C. (2005) 'Who pays? Who gains? How do costs and benefits shape the policy influence of the European Parliament?', Journal of Common Market Studies 43(3): 485-505.

Burns, C., Rasmussen, A., and Reh, C. (2013) 'Legislative codecision and its impact on the political system of the European Union', Journal of European Public Policy 20(7): 941-52.

Cirone, A. (2011) 'Opening a door: Interest group lobbying in Parliament post-Lisbon', Paper presented at the Biennial EUSA Conference, Boston, 3-5 March.

Civitas (2011) EU Facts: Pressure Groups and Lobbying in the EU, available at: http://www.civitas.org.uk/eufacts

Coen, D. and Katsaitis, A. (2013) 'Chameleon pluralism in the EU: an empirical study of the European Commission interest group density and diversity across policy domains', Journal of European Public Policy 20(8): 1104-19. 
Corporate Europe Observatory (2008) Climate Crash in Strasbourg: an Industry in Denial, available at http://corporateeurope.org/climate-and-energy/2009/01/climate-crash-strasbourg

Costa O., Dehousse, R. and Trakalová, A. (2011) Co-decision and 'Early Agreements': An Improvement or a Subversion of the Legislative Procedure? Paris: Notre Europe Studies 84.

Costello, R. and Thomson, R. (2013) 'The distribution of power among EU institutions: who wins under codecision and why?' Journal of European Public Policy 20(7): 1025-39.

De Clerck-Sachsse, J. and Kaczyński, P.M. (2009) The European Parliament-More Powerful, Less Legitimate? An Outlook for the 7th Term, Brussels: CEPS Working Document 314.

Derschewsky, K. (2008) 'What next for Brussels lobbyists? The impact of the European Parliament's increasing legislative competences on future lobbying practice in the European Union', BA thesis, University of Twente.

Dür, A. and De Bièvre, D. (2007) 'The question of interest group influence', Journal of European Public Policy 27(1): 1-12.

Dür, A. and Gemma, M. (2012) 'Who lobbies the European Union? National interest groups in a multilevel polity', Journal of European Public Policy 19(7): 969-87.

Eising, R. (2007) 'Institutional context, organisational resources and strategic choices: Explaining interest group access in the European Union', European Union Politics 8(3): 32962.

EurActiv (2007) 'Airlines call for 'more sensible' carbon-cutting scheme', 7 June, and 'Aviation and emissions trading', 11 October.

EurActiv (2011) 'Commission sets first emissions cap for aviation sector', 8 March, and 'US voices objections to EU aviation emissions ruling', 22 December.

EurActiv (2012) 'Report: US airlines may net $€ 2$ billion ETS 'windfall', 11 January.

European Commission (2006) 'Questions \& Answers on aviation \& climate change', MEMO/06/506, 20 December, Brussels.

European Commission (2013) 'Proposal for a Directive of the European Parliament and of the Council amending Directive 2003/87/EC establishing a scheme [...]', COM/2013/0722 final, 16 October.

European Parliament (2009) 'Activity Report of the Delegations to the Conciliation Committee' 1 May 2004 to 13 July 2009.

European Parliament (2012) 'Activity Report of the Delegations to the Conciliation Committee', 14 July 2009 - 31 December 2011.

Farrell, H. and Héritier, A. (2003) 'Formal and Informal Institutions under Codecision: Continuous Constitution-Building in Europe’, Governance 16(4): 577-600.

Farrell, H. and Héritier, A. (2004) 'Interorganizational negotiation and intraorganizational 
power in shared decision making', Comparative Political Studies 37(10): 1184-1212.

Farrell, H. and Héritier, A. (2005) 'A Rationalist-Institutionalist explanation of endogenous regional integration', Journal of European Public Policy 12(2): 273-90.

GreenAir (2008) 'IATA unveils environment display at Schiphol Airport to promote a green aviation image to the public', 14 October.

Greenwood, J. (2007) 'Organised civil society and democratic legitimacy in the EU', British Journal of Political Science 37(2): 333-57.

Groote, M. (2011) 'EP Plenary Debate on Emission performance: standards for new light commercial vehicles', 15 February.

Gullberg, A.T. (2011) 'Rational lobbying and EU climate policy', International Environmental Agreements: Politics, Law and Economics 8(2): 161-78.

Häge, F.M. and Kaeding, M. (2007) 'Reconsidering the European Parliament's legislative power: Formal vs. informal procedures', Journal of European Integration 29(3): 341-61.

Häge, F.M. and Naurin, D. (2013) 'The effect of codecision on Council decision-making: informalization, politicization, and power', Journal of European Public Policy 20(7): 953-71.

Hallstrom, L.K. (2004) 'Eurocratising enlargement? EU elites and NGO participation in European Environmental Policy', Environmental Politics 13(1): 175-93.

Héritier, A. (2013) 'Twenty years of legislative codecision in the European Union: experience and implications', Journal of European Public Policy 20(7): 1074-82.

Héritier, A. and Karagiannis, Y. (2011), 'The new institutions of transatlantic aviation', Global Policy 2(2): 152-62.

Hix, S. (2009) Written Evidence to the European Union Committee of the House of Lords on the Implications of codecision for national parliamentary scrutiny, published on 12 May 2009.

House of Lords (2009) 'Codecision and national parliamentary scrutiny: European Union Committee, 17th Report, available at

http://www.publications.parliament.uk/pa/ld200809/ldselect/ldeucom/125/12502.htm (accessed July 2013)

Huber, K. and Shackleton, M. (2013) 'Codecision: a practitioner's view from inside the Parliament', Journal of European Public Policy 20(7): 1040-55.

Judge, D. and Earnshaw, D. (2002) 'No simple dichotomies: lobbyists and the European Parliament', Journal of Legislative Studies 8(4): 61-79.

Kardasheva, R. (2009) Legislative Package Deals in EU Decision-Making, Research Paper, European Institute of the London School of Economics, London.

Kardasheva, R. (2012) Trialogues in the EU Legislature, Research Paper, Department of European and International Studies, King's College, London. 
Keating, D. (2013) 'Commission proposes to adjust aviation emission rules', European Voice, 16 October.

Klüver, H. (2013) Lobbying in the European Union: Interest Groups, Lobbying Coalitions, and Policy Change, Oxford: Oxford University Press.

Lehmann, W. (2009) 'The European Parliament', in: D. Coen and Richardson, J. (eds), Lobbying the European Union. Institutions, Actors, and Issues, Oxford: Oxford University Press, pp. 39-69.

Marshall, D. (2010) 'Who to lobby and when: Institutional determinants of interest group strategies in European Parliament committees', European Union Politics 11(4): 553-75.

Michalowitz, I. (2004) 'Analysing structured paths of lobbying behaviour: Why discussing the involvement of civil society does not solve the EU's democratic deficit', Journal of European Integration 26(2): 145-73.

Müller, P. and Slominski, P. (2013) 'Agree now - pay later: escaping the joint decision trap in the evolution of the EU emission trading system', Journal of European Public Policy 20(10): $1425-42$.

Neuhold, C. and de Ruiter, R. (2010) 'Why is fast track the way to go? A quantitative and qualitative analysis of the first reading procedure in co-decision', Paper presented at the European Consortium for Political Research, Porto, June 2010.

Rasmussen, A. and Reh, C. (2013) 'The consequences of concluding codecision early: trilogues and intra-institutional bargaining success', Journal of European Public Policy 20(7), 1006-24.

Reh, C., Héritier, A., Bressanelli, E. and Koop, C. (2012) 'The informal politics of legislation: Explaining secluded decision making in the European Union', Comparative Political Studies 20(10): $1-31$.

Ripoll Servent, A. (2013) 'Holding the European Parliament responsible: policy shift in the Data Retention Directive from consultation to codecision', Journal of European Public Policy 20(7): 972-87.

Saurugger, S. (2008) 'Interest groups and democracy in the European Union', West European Politics 31(6): 1274-91.

Schulz M. (2012) Acceptance speech, 17 January, European Parliament, available at http:/www.europarl.europa.eu/resources/library/media/20120117MLT35533/20120117MLT35 533.pdf (accessed July 2013).

Skodvin, T., Gullberg, A.T. and Aakre, S. (2010) 'Target-group influence and political feasibility: the case of climate policy design in Europe', Journal of European Public Policy 17(6): $854-73$.

Stie, A.E. (2010) 'Co-decision - the panacea for EU democracy?' Doctoral thesis, ARENA Centre for European Studies, University of Oslo. 
Wonka, A. and Warntjen, A. (2004) 'The Making of Public Policies in the European Union', in: A. Warntjen and Wonka, A. (eds), Governance in Europe - The Role of Interest Groups, BadenBaden: Nomos.

Yordanova, N. (2011) 'The European Parliament: in need of a theory', European Union Politics 12(4): 597-617. 


\section{Annex 1: List of interviews}

Policy Consultant, Alber \& Geiger, 21.6.2012

Official, European Parliament, LIBE, 5.7.2012

Official, European Parliament, LIBE, 6.7.2012

Official, European Parliament, ITRE, 6.7.2012

Official, European Parliament, ENVI, 13.7.2012

Desk Officer, Greenpeace, 13.7.2012

Desk Officer, EU Commission (DG CLIMA), 17.7.2012

Official, Coreper working group Environment, 24.7.2012

Official, Coreper working group Transport, 24.7.2012

Official, Coreper working party Aviation, 24.7.2012

Official, EPACA, 8.8.2012 


\section{Annex 2:}

Statistics on concluded codecision procedures

(by date of signature)

7th Legislature - from 14 July 2009 until 12 June 2013

\begin{tabular}{|c|c|c|c|c|}
\hline 1st reading & early 2nd reading & 2nd reading & $\begin{array}{c}\text { 3rd reading } \\
\text { (conciliation) }\end{array}$ & Total COD files \\
\hline 237 & 22 & 25 & 7 & 291 \\
\hline $81 \%$ & $8 \%$ & $9 \%$ & $2 \%$ & $100 \%$ \\
\hline 15 & 25 & 33 & 29 & $\begin{array}{c}\text { Average length of } \\
\text { procedure time } \\
\text { (in months) }\end{array}$ \\
\hline
\end{tabular}

7th Legislature - 14 July 2009 - 31 December 2011 (mid-term)

\begin{tabular}{|c|c|c|c|c|}
\hline 1st reading & early 2nd reading & 2nd reading & $\begin{array}{c}\text { 3rd reading } \\
\text { (conciliation) }\end{array}$ & Total COD files \\
\hline $\mathbf{1 4 3}$ & $\mathbf{1 3}$ & $\mathbf{2 0}$ & $\mathbf{7}$ & $\mathbf{1 8 3}$ \\
\hline $\mathbf{7 8} \%$ & $\mathbf{7 \%}$ & $\mathbf{1 1} \%$ & $\mathbf{4} \%$ & $\mathbf{1 0 0 \%}$ \\
\hline 15 & $<23$ & 33 & 29 & $\begin{array}{c}\text { Average length of } \\
\text { procedure time } \\
\text { (in months) }\end{array}$ \\
\hline
\end{tabular}

6th Legislature - 1st May 2004 - 13 July 2009

\begin{tabular}{|c|c|c|c|c|}
\hline 1st reading & early 2nd reading & 2nd reading & $\begin{array}{c}\text { 3rd reading } \\
\text { (conciliation) }\end{array}$ & Total COD files \\
\hline 321 & 42 & 61 & 23 & 447 \\
\hline $72 \%$ & $9 \%$ & $14 \%$ & $5 \%$ & $100 \%$ \\
\hline 17 & 27 & 34 & 45 & $\begin{array}{c}\text { Average length of } \\
\text { procedure time } \\
\text { (in months) }\end{array}$ \\
\hline
\end{tabular}

Source: European Parliament, Codecision Unit; Activity Reports of EP Conciliation Delegations 
Table

\begin{tabular}{|c|c|c|c|c|}
\hline & $\begin{array}{l}\text { Commission's } \\
\text { proposal } \\
\text { (20 December 2006) }\end{array}$ & $\begin{array}{l}\text { Council's common } \\
\text { position } \\
\text { (18 April 2008) }\end{array}$ & $\begin{array}{l}\text { Parliament's } \\
\text { recommendation for } 2^{\text {nd }} \\
\text { reading } \\
\text { (4 June } 2008 \text { ) }\end{array}$ & $\begin{array}{l}\text { Agreement between } \\
\text { Parliament, Council \& } \\
\text { Commission } \\
\text { (26 June 2008) }\end{array}$ \\
\hline $\begin{array}{l}\text { Ensuring inclu- } \\
\text { sion of aviation } \\
\text { in the EU-ETS } \\
\text { results in emis- } \\
\text { sions reducti- } \\
\text { ons from the } \\
\text { aviation sector }\end{array}$ & $\begin{array}{l}\text { Aviation included } \\
\text { into the existing } \\
\text { EU ETS with open } \\
\text { trading permitted } \\
\text { between airlines and } \\
\text { other sectors. }\end{array}$ & $\begin{array}{l}\text { Same as } \\
\text { Commission. }\end{array}$ & $\begin{array}{l}\text { Restrict the number of } \\
\text { allowances that aircraft } \\
\text { operators can buy from } \\
\text { other sectors or from } \\
\text { CDM/JI. Only aircraft } \\
\text { operators that improve } \\
\text { their efficiency at a } \\
\text { given rate are allowed } \\
\text { to buy from other } \\
\text { sectors }\end{array}$ & $\begin{array}{l}\text { Airlines will be able to } \\
\text { trade allowances in } \\
\text { an open market, i.e. } \\
\text { across sectors. }\end{array}$ \\
\hline $\begin{array}{l}\text { Geographic } \\
\text { scope and } \\
\text { starting dates }\end{array}$ & $\begin{array}{l}\text { Intra-EU flights in } \\
\text { 2011. All flights arri- } \\
\text { ving and departing } \\
\text { EU airports in } 2012 \text {. }\end{array}$ & $\begin{array}{l}\text { All flights from } \\
2012 \text {. }\end{array}$ & All flights from 2011. & All flights from 2012. \\
\hline \multicolumn{5}{|l|}{$\begin{array}{l}\text { Permit } \\
\text { allocation }\end{array}$} \\
\hline $\begin{array}{l}\text { First Period } \\
(2012)\end{array}$ & $\begin{array}{l}\text { Aviation should have } \\
\text { as much auctioning } \\
\text { as the average of } \\
\text { other sectors in the } \\
\text { EU ETS (estimated } \\
\text { at } 3 \% \text { auctioning) }\end{array}$ & $\begin{array}{l}10 \% \text { auctioning of } \\
\text { permits }\end{array}$ & $\begin{array}{l}25 \% \text { auctioning of } \\
\text { permits }\end{array}$ & $\begin{array}{l}15 \% \text { auctioning of } \\
\text { permits. }\end{array}$ \\
\hline $\begin{array}{l}\text { Subsequent } \\
\text { periods } \\
\text { (2013 } \\
\text { onwards) }\end{array}$ & $\begin{array}{l}\text { Aviation should be } \\
\text { treated as energy } \\
\text { intensive industrial } \\
\text { sectors: auctioning } \\
\text { should start as } 20 \% \\
\text { in } 2013 \text { and go up to } \\
100 \% \text { in } 2020 \text {. }\end{array}$ & $\begin{array}{l}\text { The percentage to } \\
\text { be auctioned may } \\
\text { be increased as } \\
\text { part of the general } \\
\text { review of this direc- } \\
\text { tive (i.e. similar to } \\
\text { the Commission } \\
\text { Proposal). }\end{array}$ & $\begin{array}{l}\text { The percentage to be } \\
\text { auctioned shall be } \\
\text { increased, according to } \\
\text { the maximum level of } \\
\text { auctioning in other } \\
\text { sectors (i.e. } 100 \% \text { as } \\
\text { the Commission pro- } \\
\text { posed for the power } \\
\text { sector). }\end{array}$ & $\begin{array}{l}15 \% \text { auctioning of } \\
\text { permits, but this } \\
\text { percentage may be } \\
\text { increased as part of } \\
\text { the general review of } \\
\text { the ETS directive }\end{array}$ \\
\hline
\end{tabular}

Adapted from: Corporate Europe Observatory, Climate Crash in Strasbourg: an Industry in Denial, December 2008

Word count: 7921 words 